\title{
Social Media as a Communication Strategy in Voter Education By KPUSurabaya City During The Covid-19 Pandemic
}

\author{
Rahmanu Wijaya ${ }^{1},{ }^{*}$ Puspita Sari Sukardani ${ }^{2}$, Trenda Aktiva Oktariyanda ${ }^{3}$ \\ ${ }^{1,2,3}$ Universitas Negeri Surabaya \\ *Corresponding author. Email: rahmanuwijaya@unesa.ac.id
}

\begin{abstract}
The District/ City Election Commission based on the provisions of Article 16 paragraph (3) of PKPU No. 8 of 2017 has the authority to organize voter education, the goal is to form dignified voters so as to produce regional leaders with integrity in managing the government. But in the implementation of regional head elections in 2020 held with various restrictions, so that it can potentially hamper voter education. This research examines the use of social media as a communication strategy in voter education by the Surabaya City KPU, which is related to aspects of authority and the effective use of content. Research methods are carried out normatively by reviewing the laws and regulations, and qualitatively through extracting data to a conclusion. The results of the study showed the authority of the Surabaya City KPU, following all the content in social media as voter education.
\end{abstract}

Keywords: Local Elections, Voter Education, Social Media

\section{INTRODUCTION}

Regional head elections in Indonesia in 2020 are very different from previous elections, because this is the first time that elections have been held during the Covid-19 pandemic. The condition of opposition occurs, where the election is essentially a democratic party so that it requires crowds. While pandemic conditions are suffering, including as in Presidential Decree No. 6 of 2020 has been ordered to avoid crowds. Because the election is essentially a party and a pandemic is suffering, then the General Election of the Head of the pandemic period is a party in the midst of suffering.

1. Program planning and Budget;

2. Drafting and Signing of The Regional Grant Agreement (NPHD) Text;
3. Submission of The List of Potential Residents of Electoral Voters; and

4. Registration of Prospective Individuals.

When entering the stage of the formation of PPK and PPS that had been scheduled to be carried out, experiencing delays so that it was held in the pandemic period. So this shows the attitude of the Government of Indonesia in terms of holding regional head elections that are still held despite the pandemic period, so that successive stages are the next :

1. Establishment of PPK and PPS (15 June 2020 31 January 2021) and KPPS (24 November 23 December 2020);

2. The Administration and Preparation of the Electoral Register (18 July - 16 August 2020); 
3. Public Announcement and Response to Provisional Voter List (DPS) (September 22 October 1, 2020);

4. Registration of Candidate Couples (September 4 - September 6, 2020);

5. Health Checkup (September 4 - September 11, 2020);

6. Determination of Candidate Pairs (September 23, 2020);

7. Implementation of Campaign (26 September 5 December 2020);

8. Implementation of The Vote (9 December 2020);

9. Counting and Announcement of Vote Counting Results (9 - 15 December 2020)

10. Resolution of Violations and Disputes of Election Results (Constitutional Court Schedule)

In this case, the overall implementation of regional head elections during the pandemic is based on KPU Regulation Number 6 of 2020, the principle is to carry out the election stages in abnormal conditions. Outside of these stages based on the provisions of Article 16 paragraph (3) PKPU RI No. 8 of 2017, the KPU RI, including the Regency/City KPU, has the authority to organize voter education. The meaning of voter education as conveyed by the RI KPU in the article is an effort to instill values related to elections and democracy in the life of the nation and state to citizens who have fulfilled the requirements as voters in elections or potential voters in a later period of time. Article 1 number 13 of PKPU 8 of 2017 even explicitly states that voter education is the process of conveying information to voters to increase knowledge, understanding, and awareness about elections. Furthermore, Article 3 of the PKPU states that one of the targets of voter education (besides socialization and community participation) is to disseminate information about the stages, so that it is concrete that voter education is the obligation of the Regency/City KPU which is linear with the stages of the election. This means that although it is not included as a special stage, in principle voter education is still carried out even during the pandemic.

Based on the provisions of Article 16 paragraph (2) letter g PKPU 8 of 2017, opening up leeway for every Regency / City KPU in Indonesia in terms of realizing forms of voter education. In line with the principle of health and safety as in Article 2 paragraph (2) of PKPU 6 of 2020, social media is a communication strategy that can be raised in terms of voter education and it became a record in the coordination meeting between KPU Regency / City in East Java on August 28, 2020, namely in order to pursue the number of $77.5 \%$ voter participation.[1] Simply put, social media, as according to Kaplan \& Haenlein, is an internet-based application that allows the creation and exchange of content created by its users.[2]

Related to the use of social media as a form of voter education that has been agreed to be a strategy carried out in the East Java region, it is certainly also carried out by the Surabaya KPU. Referring to the number of Surabaya DPT which is 2,089,027 voters consisting of men 1,016,395 and women 1,072,632, the people of Surabaya who exercised their voting rights in the regional head elections in 2020 only 1,098,469 or only about 52.4\% and this was determined as the lowest number in the East Java region that used their voting rights.[3] It is an irony, that Surabaya is the capital of East Java Province which is a modern society with the advancement of information technology but it turns out that in terms of voter education using social media has not been quite able to produce encouraging participation. Therefore, this research is to examine how the use of social media by the KPU of Surabaya City as a communication strategy in voter education during the Covid-19 pandemic?

\section{METHODS}

The study uses qualitative methods, with statute approaches and descriptive approaches. Namely conducting an inventory and legal analysis of related laws and regulations, some of which are PKPU Number 8 of 2017 and PKPU Number 6 of 2020. The analysis was conducted related to aspects of the authority of the Regency / City KPU in terms of the use of social media as a form of voter education in addition to also reviewing matters related to the role of voter education. Data collection techniques in a descriptive approach are carried out by interviews and documentation studies, in the end the entire data is drawn to conclusions to be able to answer the formulation ofthe problem.

\section{RESULTS AND DISCUSSION}

Political participation is one of the central issues in a general election, including regional head elections. This is because participation will be directly proportional to legitimacy, that the leader or office in power with a high participation rate then in fact that is strong political legitimacy.[4] Ideally, the government and the positions that come from the election will always have a relationship with the people, when the people who are actually constituents in an election show symptoms of 
low voter turn-out then popular support for the government will be low.[5]

The importance of this political legitimacy causes voter education agendas whose big theme to increase voter participation must be appropriate, failures in voter education have an effect on the participation rate that later risks the legitimacy of the government when it has been elected.

\subsection{Regional Head Elections during the Pandemic Period in 2020}

The Covid-19 pandemic is indeed an unexpected situation, it was emphasized in Presidential Decree No. 11 of 2020 and later in Presidential Decree No. 12 of 2020. That in Presidential Decree 11 of 2020, based on the extraordinary rate of spread of COVID-19, it was marked by the number of death and so on, it is defined as a health emergency. Furthermore, based on Presidential Decree 12 of 2020 which refers to Law Number 24 of 2007 concerning Disaster Management, namely the massive spread of COVID-19, this is qualified as a national disaster, specifically a nonnatural disaster. As a result of the determination of the disaster, there are various restrictions. Sometimes the restrictions referred to are actually related to human rights or the rights of citizens, some of which are education. Based on the Circular of the Minister of Education and Culture Number 4 of 2020, there is a "transfer" of the form or model of education from what was originally at school to education at home. Although in principle the basic right in the form of education has not been erased, in fact in form it has been reduced. Likewise work, there are restrictions in terms of work. Must be done from home, as well as business there are restrictions, and so on. Concretely, in many ways, the pandemic has caused many restrictions. Included in this is in the political field, specifically related to regional head elections. As it is known that based on Article 201 paragraph (6) of Law Number 10 of 2016 Indonesia has a national agenda to hold a democratic party in the form of a regional head election on September 23, 2020. However, due to the pandemic, it is based on a Government Regulation in Lieu of Law (Perpu) 2 of 2020 has been postponed to December 9, 2020. Talking about the postponement of the regional head election, Law Number 10 of 2016 only regulates the follow-up and follow-up elections, there is no norm that regulates the postponement of the Regional Head General Election. So that the postponement of the four stages of regional elections carried out by the KPU is only "temporary". Because the stages of the Pilkada are regulated by law, it is true that what can be the basis for the postponement must also be in theform of a law, whether it is a revision of the Law on the General Election of Regional Heads or Perppu.[6] Regarding the extent of the delay, the election organizers, the DPR and the Government as well as everything at the central level have coordinated intensively to find a solution as soon as possible regarding the postponement of the regional head election. At the end of March 2020, a Hearing Meeting (RDP) was held between Bawaslu, KPU, DKPP, Minister of Home Affairs and DKPP and resulted in an agreement on 3 options for postponing the election. First: postponement of 3 months on December 9, 2020. Second: postponement of 6 months on March 17, 2021 and third: postponement of 12 months on September 29, 2021. The construction that was built in Perpu 2/2020, regulates 3 (three) provisions, namely: first, changing the provisions regarding further elections and follow-up elections in Article 120 of Perpu 2/2020 by adding a non- natural disaster factor. Second, adding theprovisions of Article 122A of Perpu 2/2020regarding the mechanism for the implementation of continued simultaneous elections. In this provision, it is stated that further simultaneous elections will be carried out after the issuance of the decision to postpone the stages of holding simultaneous elections with a KPU Decree. The determination of the postponement of the stages of implementing the 2020 simultaneous elections, as well as the implementation of the continued simultaneous elections are decided in a Working Meeting / Hearing Meeting. Third, adding the provisions of Article 201A of Perpu 2/2020 regarding simultaneous voting. The provision stipulates that the simultaneous voting as referred to in Article 201 paragraph (6) of Law $10 / 2016$ (i.e. in September 2020), is postponed due to a non- natural disaster as referred to in Article 120 paragraph (1) of Perpu 2/2020. In the explanation it is stated that the simultaneous voting in September 2020 cannot be carried out as scheduled due to the national disaster of the covid-19 pandemic. In the event that simultaneous voting cannot be carried 
out in December 2020, the simultaneous voting is postponed and rescheduled immediately after a nonnatural disaster ends, through the mechanism as referred to in Article 122A of Perpu 2/2020. In the explanation, it is stated that the simultaneous voting in December 2020 is postponed and rescheduled if it cannot be carried out because the national disaster of the Covid-19 pandemic has not ended. This is so that talking about the polemic of delaying the implementation of the 2020 regional head elections has been completed, both from the legal aspect, talking about its legitimacy, including other aspects.[7]

In principle, because its validity has been legally recognized, other aspects, including those concerning the regions holding regional head elections, will be "set aside". In this case, it turns out that Indonesia is not "alone" as a country holding local elections during the pandemic, South Korea is recorded as the first country to hold elections in the midst of the COVID-19 pandemic whose voting was held on April 15, 2020 and held in approximately 14,000 (four twelve thousand) polling stations (TPS). Voters are required to wear masks and have their body temperature checked upon arrival. If the body temperature shows more than 37.5 degrees Celsius, the person concerned is directed to a special room. Every voter is required to use hand sanitizer and disposable plastic gloves in the voting booth and maintain a 1 meter distancebetween one voter and another. Among registered voters, there are 2,800 (two thousand eight hundred) COVID-19 patients. Electoral Organizersallow them to vote by mail before voting and create special TPS. Meanwhile, 13,000 (thirteen thousand) voters who are subject to selfisolation are allowed to vote after other voters leave the polling station at $6 \mathrm{PM}$.[8]

Learning from the local elections taking place in South Korea, the next scheme is how to "make peace" with the pandemic at the stage of regional head elections, as outlined in KPU Regulation No. 6 of 2020 has been regulated in such a way as to avoid crowds and other matters related to the enforcement of health protocols. Including in this case is also regulated regarding the authority of the KPU, and supervisory agencies in order to enforce health protocols during the election stage ofregional heads.

\subsection{The Use of Social Media by KPU Surabaya as a Means of Communication in Voter Education during the Pandemic}

Returning to KPU Regulation Number 6 of 2020 as a legal instrument that regulates technical matters in the implementation of regional head elections during the pandemic, the Regulation does not explicitly regulate voter education during the pandemic. Therefore, talking about voter education in 2020, it is still guided by KPU Regulation Number 8 of 2017. Referring to Article 1 number 12 of the Regulation, it is stated that voter education is the delivery of information with the intended purpose. The meaning of conveying information, in Article 16 paragraph (2) of the Regulations can be carried out in the form of: social mobilization, use of social networks, local or traditional media, election smart houses, formation of communities concerned with elections and democracy, formation of democratic agents or volunteers, and/or or other forms of achieving the goals of voter education. Several forms of activities that allow the Surabaya City Election Commission to take advantage of social media platforms, including making socialization materials in the form of memes or videos, creating content through billboards and banners, including those currently being intensely carried out by election organizers, namely participating in assisting the government in overcoming the spread of Covid. -19 which is endemic throughout the world by conducting socialization through social media. At this time, what is currently being carried out is discussion events or web discussions that are broadcast live or postponed through social media networks. Indeed, voter education must now bechanged by means of or using the Internet through social media platforms. This method is most effective at the moment, this is because voter participation in the regional elections during a pandemic is largely determined by the penetration of information. This media offers alternative choices not only to the Pilkada organizers, but also to voters and political contestants when physically their space for movement is limited to maintain physical distance from each other.[9]

The flow of information is currently growing rapidly from multi-faceted and multi sources, and one of the fast-moving platforms is social media as a form of information convergence in the current 
era.[10] Everyone can be an informant and a recipient, regardless of whether the information is politically charged or not, it is the face of today's developments in technology and information. In other words, social media provides a space called cyberspace to encourage the deliberation of democratic values such as volunteerism, egalitarianism, as well as networking in contemporary democratic conditions. Therefore, it is very important and significant to elaborate further on the existence of social media in the Indonesian middle class. The definition of digital politics can simply be described as a space for forming political ties in a technology-based society that strengthens or reduces the level of democracy. Online-based politics itself began to develop rapidly since 2008 in the United States when candidates at that time used social networking tools to attract voters as an effective campaign method. The new media strategy in the form of the internet has proven to be effective and has the capacity to exert such a large impact on elections. Basically, the definition of digital politics is literally a big arena that allows representation, participation, and articulation of interests and then synergize and contest each other through digital content as an intermediary. In simple terms, the online method orthe use of the internet network is done bymaximizing the use of communication and information media based on currently developing technology. That social media is the closestmedium to individuals so that any message from the communicator can be conveyed effectively. If ten years ago smartphones became a luxury item that not everyone could afford to own, but not now, almost everyone now owns it and has become one of the musthave properties

When referring to the map of using online media with a social media base, maximizing the function of the official website, passively soliciting elections through Instagram, Facebook, Twitter, Youtube Streaming accounts and even Tik-Tok are the best ways that KPU in the regions can use to encourage voters' interest in exercising their rights. choose it. Of course, this method must be done and packaged professionally by involving social media activists and online media influencers. Regarding the things that have been done by the Surabaya City KPU, the steps taken when communicating through social media. First, target potential users.
Not all social media users are interested in political information unless it relates to emotional and territorial affinity. Therefore, an interesting message must be conveyed on a page or fan page, for example with a local or regional approach. Netizens may not be interested in political information from areas other than their own, especially election information. Second, the use of hashtags. When posting information and photos, administrators can use appropriate and popular hashtags, so that posts can be indexed and found easily. Third, use interesting words and sentences. The use of effective language by including a subtle invitation or encouragement to find out the content of the information we send. Fourth, build two-way communication and provide a fast response to all information being disseminated.

\section{CONCLUSION}

Based on everything that has been described, it can be concluded that the logical consequence of holding regional head elections during the pandemic is that it has an effect on matters relating to technicalities, especially those that are the biggest, it could even be said to be related to voter education. This is because the success of voter education is to determine the quality of the government or everything on the results of the election, so a unique way of implementing it is needed. That it is true that the Surabaya City KPU has implemented a series of methods using social media, including being supported by the condition of the City of Surabaya as a "modern" city, in fact, is supporting the success of voter education patterns through social media. However, it turns out that voter participation as an indicator of the success of education in question, shows that Surabaya City is the area with the lowest participation in the 2020 regional head election.

So in further research, it can be studied about each content in social media that functions as votereducation. So that it can comprehensively explore the factors that caused the "failure" of voter education that took place in the Surabaya area. 


\section{REFERENCES}

[1] “KPU Bojonegoro." [Online]. Available: https://kab-

bojonegoro.kpu.go.id/2020/08/28/kpu-kajistrategi-sosialisasi-dan-pendidikan- pemilih/).

[2] A. K. \& M. HaenLein, User of The World, Unite, The Challenges and Opportunities of Social Media. 2010.

[3] "Partisipasi Pilkada Surabaya Terendah Jawa Timur."

[4] P. L. Berger, Pyramids of Sacrifice: Political Ethics and Social Change. New York: Basic Book, 1974.

[5] E. A. \& W. Berenschot, Democracy for Sale Elections, Clientelism, and the State in Indonesia. London: Cornell University Press, 2019.

[6] A. dan A. Z. Bisri, Pilkada Langsung Problem dan Prospek. Yogyakarta: PustakaPelajar, 2006.

[7] G. B. Powell, "Election laws and representative governments: Beyond votes and seats," $B r . J$. Polit. Sci., 2006.

[8] "Indonesia Tak Mampu Tiru Korsel Pemilu di Tengah Pandemi." [Online]. Available: https://www.medcom.id/nasional/politik/0k 80R7dk-indonesia-tak- mampu-tiru-korselpemilu-di-tengah-pandemi.

[9] Wiryanto, Pengantar Ilmu Komunikasi. Jakarta: PT. Gramedia Widiasarana, 2004.

[10] J. A.Schumpeter, CAPITALISM, SOCIALISM AND DEMOCRACY. New York: Taylor \& Francis e-Library, 2003. 